\title{
The Thirteen Manners of Mantra Attributed to Dīpamkaraśrījñāna
}

\author{
MOCHIZUKI Kaie
}

\section{Introduction}

As I have mentioned in the last volume of this journal, the thirteen works on the esoteric rituals attributed to Dīpaṃkaraśrījñāna are collected in the Tangyur." They are called "the thirteen manners of mantra (sngags lugs bcu gsum)" in the first work and the last. In the cover of the first text, the Mantrārthāvatāra, ${ }^{2)}$ the words are carved in small letters:

Because it is said "what the king eats is not words of the vehicle of the secret mantra," the [following works] are written in order to reject this wrong understanding. We will enter the teaching of the thirteen manners of the mantra attributed to Dīpamkara. ${ }^{3)}$

The meaning of the thirteen manners becomes clear in the colophon of the last work, the Citāvidhi. ${ }^{4)}$

The mantra manners of Dīpamkara are thirteen. If there is everything, it is marvelous. Thirteen manners are entering into the vehicle of mantra, empowerment (abhiseka), concealed commitments (samaya), offering to a celestial palace, oblation of water, burnt offering (homa), worshipping divinities, longevity practice, seducing death, explanation of the dying process, funeral practices, seven virtuous acts, and molding small statues. ${ }^{5)}$

The thirteen manners are explained in the thirteen works from the Mantrārthāvatāra to the Citāvidhi, to be added the Sekopadeśa, ${ }^{6)}$ the Samayagupti, ${ }^{7)}$ the Saudadāna, ${ }^{8)}$ the Peyotkșepavidhi, ${ }^{9)}$ the Homavidhi, ${ }^{10)}$ the Devapūjākrama, ${ }^{11)}$ the Äyuhsādana, ${ }^{12)}$ the Mrtyuvañcana, ${ }^{13)}$ the Mumūrșuśāstra, ${ }^{14)}$ the Śmahoma, ${ }^{15)}$ and the Saptaparvavidhi. ${ }^{16)}$ These thirteen works are collected under the name of "the thirteen manners of mantra attributed to Dīpamkaraśrījñāna." ${ }^{17)}$ Though the first six, beginning with a ritual of consecration, are ordinary rituals, the last six are related to the rituals of death and rebirth. I have already 
discussed the first and the last in other papers, ${ }^{18)}$ and I will consider six work on ordinary rituals from the second to the seven in this paper.

\section{Mutual Relationship of the Thirteen Rituals}

Before considering each work, I will relate the total characteristics of these works. First, their written form is not unified. Three of them are written in verse style, ten are in prose style, and eight of them are written as actual manuals of rituals and five as explanations of rituals. And all of them are accompanied footnotes written in small letters by the compiler, and the objects of worship in their beginning are unified into the female deity Tārā. This lets us imagine that Dīpaṃkaraśrījñāna did not write each work as a part of a series of his thirteen teachings of mantra, but his follower in Tibet collected them as his thirteen works on the esoteric rituals.

We can find the reason why the compiler collected them as the esoteric manners. Excepting the Sekopadeśa, in the beginning of each work he gives the purpose of each work in its footnote in order to explain the structure of these manners. On the basis of his interpretation, the Mantrārthāvatāra explains to those who want to enter into the unsurpassable secret mantra which is better than the great vehicle as a way to enter them into this secret mantra. ${ }^{19)}$ The Samayagupti is written for the purpose of keeping one's commitments after receiving initiations. ${ }^{20)}$ The Saudadāna explains to those who keep commitments how to offer to deities and gurus for the purpose to please them. ${ }^{21)}$ The Peyotksepavidhi is written for the purpose of accumulating ordinary merits and subduing obstacles. ${ }^{22)}$ The Homavidhi is written for the purpose of accumulating special merits and removing obstacles. ${ }^{23)}$ The Devapūjākrama is written for the purpose of governing accomplishment of deities of the desire realm. ${ }^{24)}$ The Āyuhsādana explains to prolong one's life because the accomplishment become worthless if a life of a Yogin is short. ${ }^{25)}$ The Mrtyuvañcana explains to deceive one's own death when a symptom of death appears. ${ }^{26)}$ The Mumūrșuśāstra explains instructions at the moment of death for expelling one's death. ${ }^{27)}$ The Śmahoma explains purification of karmic pollution and the corpse offered to assembly of deities. ${ }^{28)}$ The Saptaparvavidhi explains cessation of suffering in the middle phase (bar du) and rebirth in the highest realm of deities. ${ }^{29)}$ The Citāvidhi explains molding small statues for special merits with dependence on remains. ${ }^{30)}$

These thirteen rituals are rituals on death and rebirth on the whole. He seems to col- 
lect these thirteen works in order to reconstruct this ritual of Dīpaṃkaraśrījñāna. Because each work is written in a different style, the compiler may not have been taught them directly by Dīpaṃkaraśrīiñ̄āna.

\section{Sekopadeśa}

The Sekopadeśa is written in verse with fifty-nine lines, almost fifteen verses. This work is not a manual of the ritual on consecration, but an explanation on the two kinds of consecrations. ${ }^{31)}$ Although Dīpamkaraśrījñāna discusses the four types of consecrations and prohibits religious celibates (brahmacarya $)$ from the secret and the wisdom consecrations in his Bodhipathapradipa ${ }^{32)}$ he teaches them in this esoteric work.

In the beginning the author classified the consecration into two, the vase consecration and the knowledge of wisdom consecration. The vase consecration is further classified into two, the accomplishment consecration and the master (ācārya) consecration. The former consists of six consecrations, the water, the crown, the vajra, the bell, the name and the $\operatorname{lord}^{33)}$ consecrations. The latter consists of the deities in the mandala, teaching from actions of masters, secret reasons, and the great determination. And these two kinds of consecrations are also defined as inner consecrations and the knowledge of wisdom consecration as an outer consecration. The knowledge of wisdom consecration is also explained in two parts, about the knowledge consecration and the wisdom. In this explanation the commentator added the comment on the other two consecrations, the secret and the fourth. Therefore he read this work as the explanation of five kinds of consecrations, the vase, the master, the knowledge of wisdom, the secret, and the fourth consecration, although the author never refers to the last two.

\section{Samayagupti}

The Samayagupti explains the thirteen kinds of commitments (samaya) in verse with sixtysix lines, sixteen verses and a half. Although I could not identify the source of these thirteen commitments, the thirteen root downfalls (müläpatti) are classified into the action tantras (Kriyātantra) in the Sarvasamayasamgraha of the same author. ${ }^{34)}$

In the beginning the author mentions the relationship between consecrations and commitments, for example, those who damage their commitments can not get accomplishment of initiation. And he mentions thirteen commitments. They are (1) not to see vajra as an 
awakened mind and Vajra-holder as their gurus separately, (2) to enter their wrathfulness into prison with five brothers, listening, faculties, instructions, accomplishments and commitments, (3) not to teach words, persons, provisional meanings, and consciousness as mental processes, (4) to teach women with a picture, a conch shell, a lotus, an elephant, an dagger (phur pu), (5) to acknowledge nectars purifying flesh, (6) to recollect characteristics of mandalas in a mind, (7) to have an equal mind, (8) not to consecrate to a mother, a sage, an ascetic, a wife, a king, non-Buddhist, or a Brahman, (9) not to shout the secret teaching to those who have blames, laziness, and deceitfulness, but no bravery, (10) not to cling to mental objects like consciousness and existence without compassion and benevolence, (11) not to assume wrongly other meanings from action of commitments, reason of teaching and great seals, (12) to recollect permanence and impermanence, suffering, emptiness, selflessness, and enlightened mind, and (13) to acknowledge the namelessness of existence, the formlessness of saints, and the absence of own-being of person. In the end the Sugata is said to have taught two kinds of birth: man gets liberation if man keeps these thirteen commitments and man falls into hell if man breaks commitments.

\section{Saudadāna}

As the Saudadāna is also called "the Offering to Mandala (Ma'dal'bul)" in its colophon, this work is a short manual of ritual of mandala to offer materials for masters and the word "a celestial palace ( $g$ zhal yas khang) of deities" in the title indicates the mandala.

At first a Yogin should make all beings objects of his great compassion and recollect deities that come from three rituals. ${ }^{35)}$ He should imagine holding characteristics of body, speech and mind with three colors, white, red, and blue, which penetrate into cakra, lotus and vajra in order to empower his body, speech and mind with three words, oṃ ạh hūm. He should invite masters to come forth from seeds existing in the moon, his heart, awaken the enlightened mind with the four immeasurable minds, imagine all things like a space, and build up maṇdala coming from seeds of four words, yam bạ̣ lam pạ̣. He should empower offering with mantra, and scattering flowers and water to the mandala. He should offer them to masters and visualize a palace of jewels. In the end the author cites a verse from a $\operatorname{tantra}^{36)}$ which explains the manḍala of offering to a master or the Buddha.

Although the author explains the actual manner how to offer to the deities and masters in the mandala, there is another work on the ritual of offering in the thirteen manners. 
Therefore this work explains how to use mandala in the ritual of offering.

\section{Peyotkșepavidhi}

The Peyotksepavidhi is a practical manual of the ritual of water offering (jalabali) in prose style. Although its tittle indicates the ritual to scatter water as oblation, the author does not mention how to scatter water in this ritual. ${ }^{37)}$ Its contents consist of meditative practice, therefore this work seems to be a preliminary practice preceding the actual ritual.

The commentator classifies its contents into seven, preliminary practice, purification, radiation and reabsorption of nectar, individual transfer of merits, equal transfer, offering of material goods and teaching, and transfer by words. The procedure of this practice is as follows: (1) Those who will scatter water should pour water into a vessel, recollecting selflessness and seeing beings in the field of suffering through compassion. (2) He should remove dust of offering. (3) He should empower offering with a mantra of nectar. (4) He should chant a mantra for getting an experience without poverty of food and drink. (5) He should chant a mantra for completing his wealth without a mutual conflict. (6) He should chant a mantra for rejoicing at eyes and minds of beings and having patience with a teaching of non-arising. (7) He should get a state of treasure which satisfies body and mind of infinite sentient beings, removes all kinds of sufferings and never loses the great bliss, with the generosity of things and teaching in a meditative practice. In the end he should recite the sixtieth verse of the Yuktiṣaștika by Nāgārjuna, in which acquirement of the accumulations of merit and wisdom are taught.

The first two performances and the last are meditative practices and the middle four performances are practices chanting mantras, and there is little explanation on an actual performance to scatter water in this work.

\section{Homavidhi}

The Homavidhi is a practical manual of burnt offering in prose style. Although Dīpaṃkaraśrījñāna writes another work $^{38)}$ on the burnt offering, he explains the actual practice in this work.

The commentator classifies its contents into seven, preparation of fireplace, fire-wood, lighting a fire, visualizing Agnideva of commitments, visualizing Agnideva of wisdom, offering fire substances, and offering to the assembly of deities of wisdom at the fireplace. 
The procedure of this practice is as follows: (1) The performer should make a fireplace at the four corners of the maṇala after awakening enlightened mind. (2) He should drip milk on the fire-wood. (3) He should light a fire at the churning sticks. (4) He should visualize Agnideva wearing a necklace of rosary, holding a stick and a water vessel and riding on a gelded male goat (5) He should invite Agnideva by giving out a light from his heart and entering into it. (6) He should burn sesame, sandal wood, and saffron as offerings to Agnideva while chanting a mantra. (7) He should purify materials by smoke offering, invite his own deities, visualize an empowerment of Buddhas, offer them in the way of burning and filling, and chant a mantra. Then he should make his enlightened mind stainless and imagine entering into a state of a great bliss of non-conception and natural luminosity.

This work explains the manner to invite Agnideva and other deities with an actual performance of homa ritual. And the performer can accumulate merits and wisdom for perfection.

\section{Devapūjākrama}

The Devapūjākrama explains the order of offering in prose style. As its title means, the author explains actual steps of offering.

The commentator classifies its contents into six, the purpose of offering to deities, empowerment of offering, objects of offering, offering, actions for the benefits of beings by deities, and benefits of offerings. The procedure of this practice is as follows: (1) A beginner Yogin should offer to his own deity for his accomplishment. (2) He should empower five kinds of outer offerings and five kinds of inner offerings. ${ }^{39)}$ (3) He should invite his own deity with a ritual of visualization and offer to it. (4) He should also offer to female deities widely. (5) He should offer to an assembly of all beings. (6) The scriptures certainly show that in this way he can acquire the accomplishment just as he hopes and the mastery of the Buddha field.

The author explains the manner how to visualize deities in detail. This work may indicate how to invite the object of offering and give them inner offerings rather than the actual performance of offering.

\section{Conclusion}

Although these thirteen manners of mantra consist of thirteen works of Dīpaṃkaraśrījñāna, 
he himself does not seem to have written each work under this title. Each work is certainly compiled into a specific theme but they are written in different styles. The compiler seems to have selected his thirteen works in order to build his esoteric ritual on death and rebirth. Therefore the thirteen manners of mantra may not be the work of Dīpaṃkaraśrìjñāana, but of its compiler. In addition it is thought that they have a different tradition from his other works because other editions of these thirteen works without footnotes does not exist,

The purpose of compiling these works was to make a ritual system on the death and rebirth, because the last six works are written about the special theme on death and rebirth. And the first seven works seem to be a preliminary ritual for it. And this preliminary ritual consists of consecration, commitments, offering to a mạ̣ala, scattering water, a homa ritual, and offering to deities. I will consider the last six in my next paper.

\section{Notes}

1) They are collected in the Ganden edition, the Narthang, the Peking, but not in the Cone and the Derge.

2) Tib. sNgags kyi don 'jug pa. G. Zu 217a1-219b3, N. Zu 162b7-164b6, P. no. 4856, Zu 164b6-166a7. A. Dīpaṃkaraśrījñāna. Cf. Mochizuki 2019b.

3) Tib. P. no. 4856, Zu 164b6: rgyal po za zhes bya ba zhig gsang sngags kyi theg pa bka' ma yin zer bas / de’i log rtogs dgag pa'i ched du mdzad pa'o // Ti pạ̣ ka ra'i sngags lugs bcu gsum bzhigs pa lags sho //.

4) Tib. Tsha tsha’i cho ga. G. Zu 234a3-235a6, N. Zu 176b6-1778a1, P. no. 4868, Zu 177b4-178b5.

5) P. no. 4868, Zu 178b3-4: Ti pam ka ra’i sngags lugs bcu gsum pa'o // kun la yod na ngo mtshar che / bcu gsum ni / sngags kyi don la 'jug pa / dbang bskur ba / dam tshig sbas pa / gzhal yas khang sbyin pa / chu gtor / sbyin bsreg / lha mchod pa / tshe sgrub pa /'chi ba slu ba /'chi ka ma'i bstan chos / ro bsreg pa / bdun tshigs / tsha tshwa gdab pa dang bcu gsum mo //.

6) Tib. dBang gi man ngag. G. Zu 219b3-220b5, N. Zu 164b6-166a1, P. no. 4857, Zu 166a7-167a6. A. Dīpaṃkaraśrījñ̄āna.

7) Tib. Dam tshig sbas pa. G. Zu 220b5-222a3, N. Zu 166a1-167a4, P. no. 4858, Zu 167a6-168a7. A. Tīpamkara.

8) Tib. gZhal yas khang sbyin pa. G. Zu 222a3-223a5, N. Zu 167a4-168a4, P. no. 4859, Zu 168a7$169 \mathrm{a} 7$.

9) Tib. Chu gtor gyi cho ga. G. Zu 223a5-224a5, N. Zu 168a4-169a2, P. no. 4860, Zu 169a7-170a4.

10) Tib. sByin sreg gyi cho ga. G. Zu 224a5-225b3, N. Zu 169a2-170a3, P. no. 4861, Zu 170a4-171a5.

11) Tib. lHa mchod pa'i rim pa. G. Zu 225b3-227a3, N. Zu 170a3-171b1, P. no. 4862, Zu 171a6-172b1.

12) Tib. Tshe bsgrub pa'i thabs. G. Zu 227a3-228a4, N. Zu 171b1-172a7, P. no. 4863, Zu 172b2-173b1.

13) Tib. 'Chi ba slu ba. G. Zu 228a4-229a5, N. Zu 172b1-173a6, P. no. 4864, Zu 173b1-174a7.

14) Tib. 'Chi ka ma’i bstan bcos. G. Zu 229a5-230b3, N. Zu 173a6-174b2, P. no. 4865, Zu 174a7$175 \mathrm{a} 8$.

15) Tib. Ro bsreg pa. G. Zu 231a1-232b5, N. Zu 174b2-175b5, P. no. 4866, Zu 175b1-176b3.

16) Tib. bDun tshigs kyi cho ga. G. Zu 232b5-234a2, N. Zu 175b5-176b6, P. no. 4867, Zu 176b3-177b4. 
17) Only the four works, the first three and the last, the Mantrārtāvatāra, the the Sekopadeśa, the Samayagupti, and the Citāvidhi, are attributed to Dīpamkaraśrījñāna in their colophon and the other nine works have no information on their authors. Therefore it is possible to doubt his authority regarding the other nine works.

18) See Mochizuki 2019b on the Mantrārthāvatāra and Mochizuki 2019a on the Citāvidhi.

19) N. P. no. 4856, Zu 164b7: theg pa chen po las khyad par du gyur pa gsang sngags bla ne med pa zhugs pa'i de lta bur gyur pa gcig / gsang sngags la 'jug par'di bshad pa bya'o //.

20) P. no. 4858, Zu 167a8: dbang bskur nas dam tshig srungs dgos pas dam tshig bstan //.

21) P. no. 4859, Zu 168a8: dam tshig ldan pa des lha mnyes par byed dgos pas lha dang bla ma la gzhal yas khang sbyin pa ston //.

22) P. no. 4860, Zu 169a8: lha dang bla ma mnyes pa des thun mong du tshogs bsags cing bar chad zhi bar byed pa'i phyir chab gtor bstan te $/$.

23) P. no. 4861, Zu 170a6: khyad par du tshogs bsags pa dang / bar chad gsal bar bya bai i phyir sbyin sreg ston te $/$.

24) P. no. 4862, Zu 171a7: 'dod pa'i dngos grub dbang du bya ba'i phyir lha mchod pa ston.

25) P. no. 4863, Zu 172b3: rnal 'byor pa tshe thung na sgrub pa'i long med pas tshe sring ba'i gdam ngag bshad pa.

26) P. no. 4864, Zu 173b2: rnal 'byor pa tshe thung na sgrub pa'i long med pas 'chi bltas byung na 'chi ba slu ba bshad pa.

27) P. no. 4865, Zu 174a7: dus chen po la bab te 'chi ba ma zlog na'chi ka ma'i gdams pa ston te.

28) P. no. 4866, Zu 1752: tshe 'phos pas bag chags kyi sgrib pa sbyong ba dang phung po lha tshogs la dbul ba'i ro ston to //.

29) P. no. 4867, Zu 176b4: bar do'i du kha zhi zhing'og min la sogs par skye bar bya ba'i phyir /.

30) P. no. 4868, Zu 177b5: rten rus pa la rten nas tshogs khyad par can bsags pa’i phyir tsha tshwa ston te.

31) Advayavajra also explain the four kinds of consecration in his Sekatātparyasamgraha. See Mikkyō Seiten Kenkyūkai 1989, 108-122 and Mathes 2015, 133-145; 403-414.

32) Bodhipathapradīpa 257-260 (Eimer 1978, 138-139): dang po sangs rgyas rgyud chen las // rab tu 'bad pas bkag pa'i phyir // gsang ba shes rab dbang bkur ni // tshangs par spyod pas blang mi bya //. See also Shizuka 2012.

33) The sixth is the ācrārya consecration in the Sekatātparyasamgraha of Advayavajra and the bell consecration is also called the lord in it. The Kriyāsamgraha refers to the five consecrations and the ācārya consecration is classified into another category. Although Dīpamkaraśrījñāna counts six the same way as Advayavajra, he classified the sixth into another category like the Kriyāsamgraha. Therefore he may have called the sixth the lord consecration. See Mikkyō seiten kenkyūkai 1989, 109-117; Mathes 2015; 134-138; Sakurai 1996, 87-158, and Skorupski 2002, 115-119.

34) Tib. Dam tshig thams cad bsdud pa. D. no. 3725, Tshu 45a3-5, P. no. 4547, Nu 255a3-6: de la rkang grangs ni thun mong gi rtsa ba’i ltung ba bzhi dang pha rol tu phyin pa’i rtsa ba’i ltung ba bcu gnyis dang kri ya'i rgyud kyi rtsa ba'i ltung ba bcu gsum dang / spyod pa'i rgyud kyi rtsa ba'i ltung ba bcu bzhi dang rnal 'byor gyi rgyud kyi rtsa ba'i ltung ba bcu bzhi dang / rnal 'byor chen po'i rgyud kyi rtsa ba'i ltung ba bcu bzhi dang / yang lnga dang yang bzhi dang / rtsa ba'i ltung ba bdun cu tham pa'o // de la yan lag gi dam tshig rnams ni'di rnams so zhes bgrang bar mi nus te / mdo sde dang mngon pa dang 'dul ba dang rgyud sde rnams su blta bar bya'o //. See Endō 2008, 203-204. As Endō indicates, Bu ston and Tsong kha pa reads "thirteen (bcu gsum)" to "thirty (sum cu)." mKhas grub rjes has doubt of his authority. See also Lessing and Wayman 1968, 154-155. 
35) The author does not mention what the three preceding rituals are.

36) Although the commentator calls it "Tantra of eleven comprehension of Avalokitesvara (sPyan ras gzigs rtogs pa bcu gcig pa'i tan tra)," I have not been able to identify it.

37) Dīpaṃkaraśrījñāna writes another ritual on water oblation, the *Jalabalivimalagrantha (D. no. 3779, P. no. 4597). See Mochizuki 2018, 165-166

38) There is another Homavidhi (D. no. 2659, P. no. 3483) written in verse by the same author. See Mochizuki 2019a, 154-155.

39) The author mentions five inner offerings, that is to say, materials, mantras, seals, meditations and songs, but does not mentions what the inner five are.

\section{Bibliography}

Eimer, Helmut. 1978. Bodhipathapradīpa: Ein Lehrgedicht des Atiśa (Dīpaṃkaraśrījñ̄āna) in der Tibetischen Überlieferung. Wiesbaden: Otto Harrassowitz.

Endō Yūjun 遠藤祐純. 2008. Kairitsu gaisetsu: Shoki Bukkyō kara mikkyō $e$ 戒律概説: 初期仏教から密教 ح. Tokyo: Nonburu Sha.

Lessing, F. D., and Alex Wayman. 1968. Introduction to the Buddhist Tantric Systems. Hague: Mouton.

Mathes, Klaus-Dieter. 2015. A Fine Blend of Mahāmudrā and Madhyamaka: Maitrīpa's Collection of Texts on Non-conceptual Realization (Amanasikāra). Wien: Verlag der Österreichischen Akademie der Wissenschaften.

Mikkyō Seiten Kenkyūkai 密教聖典研究会. 1989. “Adovayavajura chosakushū: Bonbun tekisuto: wayaku (2)”アドヴァヤヴァジュラ著作集：梵文テキスト・和訳(2). Taishō Daigaku Sōgō Bukkyō Kenkyūjo nenpō 大正大学綜合仏教研究所年報11: 86-145.

Mochizuki Kaie 望月海慧. 2018. “On the Works on the Ritual of Oblation Attributed to Dīpamkaraśrījñāna.” Indogaku Bukkyōgaku kenkyū 印度学仏教学研究 66(3): 163-170.

— 2019a. "Five Remaining Works on the Esoteric Ritual of Dīpamkaraśríjñāna." Indogaku Bukkyōgaku Kenkyū 印度学仏教学研究 67(3): 153-160.

2019b. “Atisha no Mantoraginyū ni tsuite” アティシャの『マントラ義入』について. Shūkyo kenkyū宗教研究 80 (Supplement): 369-370.

Sakurai Munenobu 桜井宗信. 1996. Indo mikkyō girei kenkyū インド密教儀礼研究. Kyoto: Hōzōkan.

Shizuka Haruki 静春樹. 2012. “Kongōjō no biku Atisha to himitsu-hannyachi kanjō kinshi no mondai” 金剛乗の比丘アティシャと秘密·般若智灌頂禁止の問題. Indogaku Bukkyōgaku kenkyū 印度学仏教 学研究 61(1): 107-112.

Skorupski, Tadeusz. 2002. Kriyāsamgraha: Compendium of Buddhist Rituals: An Abridged Version. Tring: Institute of Buddhist Studies.

(This research was supported in part by a Grant-in-Aid for Scientific Research (A) from JSPS no. 18H03569)

Key words Dīpaṃkaraśrīiñ̄āna, Atiśa, ritual, vidhi, abhiṣeka, samaya, mạ̣ḍala, jalabali, homa, pūja

(Professor, Minobusan University, D.Lit.) 